Journal of Bangladesh Academy of Sciences, Vol. 36, No. 1, 45-51, 2012

\title{
BACKGROUND CHEMICAL STUDY OF RELOCATED HAZARIBAGH TANNERY COMPLEX ENVIRONMENT, SAVAR
}

\author{
Y. N. JOLLY, T. R. CHOUDHURY, A. ISLAM*, N. I. SURAVI ${ }^{1}$ AND M. S. SULTANA ${ }^{1}$ \\ Chemistry Division, Atomic Energy Centre, P.O. Box 164, 4, Ramna, Dhaka 1000, \\ Bangladesh
}

\begin{abstract}
A background study of the chemical constituents of some environmental samples - tannery complex sand, river water, river sediment and river fishes collected from the Relocated Hazaribagh Tannery Complex (RHTC) area, was carried out. In sand samples the mean values for $\mathrm{pH}, \mathrm{EC}$ and soluble salts were found to be $8.49,0.02 \mathrm{mS} / \mathrm{cm}$ and $11.72 \mathrm{mg} / \mathrm{kg}$ and the mean concentrations of elements K, Ca, Ti, Mn, Fe, Co, Zn, As, Pb, Rb and $\mathrm{Sr}$ were 94.8, 68.5, 16.6, 2.68, 129, 1.19, $0.23,0.70,0.32,0.62$ and $1.03 \mathrm{mg} / \mathrm{kg}$, respectively. In river water samples the average concentrations of $\mathrm{K}, \mathrm{Ca}, \mathrm{Mn}, \mathrm{Fe}, \mathrm{Zn}, \mathrm{As}, \mathrm{Rb}, \mathrm{Sr}, \mathrm{SO}_{4}^{-2}, \mathrm{PO}_{4}^{-3}, \mathrm{Cl}^{-1}$ and $\mathrm{NO}_{3}^{-1}$ were 13.09, 178, $0.41,1.82,0.073,0.031,0.010,0.48,0.057,0.019,15.6,5.68 \mathrm{mg} / \mathrm{l}$ and the average values for $\mathrm{pH}$, EC, DO, BOD, SS and DS were 8.02 and $0.35 \mathrm{mS} / \mathrm{cm}, 6.29,4.21,0.06,0.36 \mathrm{mg} / \mathrm{l}$, respectively. The elements $\mathrm{K}, \mathrm{Ca}, \mathrm{Ti}, \mathrm{Cr}, \mathrm{Mn}, \mathrm{Fe}, \mathrm{Ni}, \mathrm{Cu}, \mathrm{Zn}, \mathrm{As}, \mathrm{Rb}, \mathrm{Sr}$ and $\mathrm{Pb}$ were measured in river sediment samples at the limit of 205, 155, 67, 6.02, 17.2, 798, 1.10, 1.24, 1.99, 0.31, 2.34, 2.63 and 0.35 $\mathrm{mg} / \mathrm{kg}$, respectively. In some locally available fishes like tengra, puti, baim, taki, shrimp, chanda and baila, only the elements $\mathrm{K}, \mathrm{Ca}, \mathrm{Fe}, \mathrm{Zn}, \mathrm{Rb}$ and $\mathrm{Sr}$ could be measured in all species of fishes in the range of $0.39-1.01,0.68-2.29,60.6-125,46.3-174,2.84-61.8$ and $12.3-38.0 \% \mathrm{in} \mathrm{mg} / \mathrm{kg}$, respectively. In the light of the overall study, the chemical constituent levels of the environmental samples of the RHTC area at present are low and the environment is not yet contaminated.
\end{abstract}

Key words: Environmental samples, Chemical constituents, EDXRF, AAS

\section{INTRODUCTION}

The most pollution creating industries of Bangladesh are the tanneries concentrated mainly in Hazaribagh in the south-western part of Dhaka city. As the tanneries are on the bank of the Buriganga, this river has been the disposal point of all liquid effluent all along from the beginning of the operation of these industries where both liquid and solid wastes are produced. The tannery units release thousands of cubic metres of untreated toxic waste everyday to the Buriganga and the water of the river has turned black. The river bed has accumulated a huge deposition of settled solid wastes. The aqueous environment of the river has been totally unhealthy for the survival of the aquatic animals. During the rainy season when the river water overflows the bank, the polluted water contaminate the

* Corresponding author:

${ }^{1}$ Department of Environmental Sciences, Jahangirnagar University, Savar, Bangladesh. 
surrounding agricultural land. The stagnant effluent in the adjacent ditches of tanneries, the open unmetalled effluent carrying drains and the solid wastes kept deposited here and there have been threatening to the densely populated residential area of Hazaribagh for long. As a matter of fact, the environment of whole Hazaribagh and its surrounding area has totally been degraded due to the mismanagement of highly toxic effluent generated from the Hazaribagh tanneries and other effluent producing industries in the area.

Realizing the hazardous impact of tannery wastes on human and environment, the Government has taken a project "Hazaribagh Tannery Relocation Project (HTRP)" to shift Hazaribagh Tannery Complex to a new site in Savar for which acquisition of 200 acres of land and the earth filling work and the installation of water and power lines have been completed. The main objective of the present research was to study the status of the background chemical composition of the environment of the new Hazaribagh tannery complex and its surroundings which will contribute generation of useful data that may be used as reference for further environmental monitoring in future.

\section{MATERIALS AND METHODS}

Ten samples of sand from Relocated Hazaribagh Tannery Complex (RHTC) and ten samples of water and sediment, and five species of fish were collected from the river flowing beside RHTC in fresh polyethylene containers. The solid sample preparation involved the processes of oven drying at $60^{\circ} \mathrm{C}$ overnight and grinding for making powder. The effective analysis of the water sample required preconcentration in preparation process which was performed through direct evaporation of $200 \mathrm{ml}$ of sample to $10 \mathrm{ml}$ on water bath for Atomic Absorption Spectrophotometer, (AAS) analysis. Besides, the preconcentration was also carried out by absorbing the sample $(300 \mathrm{ml})$ on analar grade cellulose powder $(0.1 \mathrm{~g})$ taken in a porcelain dish through evaporation on water bath (XRF analysis). The cellulose absorbed sample was dried at $60^{\circ} \mathrm{C}$ overnight, weighed, transferred to a carbide mortar and ground to fine powder and preserved in desiccator in a polyethylene bag. Fish samples were digested using microwave digestion system.

Electrical conductivity (EC) and $\mathrm{pH}$ were measured using a Jeneway EC and $\mathrm{pH}$ meters. The elemental analysis in solid and liquid matrices was carried out using isotopic source-based EDXRF (Energy Dispersive X-ray Florescence) and flame AAS techniques, respectively. Anions were measured by standard methods based on UV-visible spectrometry and Ion Selective Electrode techniques.

For X-ray irradiation, the powdered solid sample (100 mg) was pressed into a pellet using a Perkin Elmer pellet maker and irradiated by an X-ray beam emitted from a radioisotope source (Cd-109) for excitation of elemental characteristic X-rays. The standards were also irradiated under similar conditions. 
The standards were run first for absorbance measurement using the concerned cathode lamp and then the unknown samples. Triplicate readings were taken for each measurement. The samples were diluted where necessary. The blank sample was always run against the experimental one.

The elemental peak areas of the sample spectra of samples and standards were integrated using a QXAS software programme. A calibration curve (X-intensities vs Atomic number) was constructed based on the elemental X-ray intensities and their known concentrations. The concentrations of elements in the unknown samples were calculated using calibration factor obtained from the curve.

A three point calibration curve (Absorbance vs concentration) was made from the average absorbance of the standard element. The elemental concentration in the real sample was calculated using calibration factor of the curve.

\section{RESULTS AND DISCUSSION}

Results obtained for tannery complex sand, river water, river sediment and fish samples are shown in range in Table 1.

Results are discussed below in terms of mean values of triplicate measurements for each matrix of samples.

The RHTC sand samples were analysed for physicochemical and trace element levels. The average values of $\mathrm{pH}, \mathrm{EC}$ and soluble salts in the samples were found to be 8.49, $0.02 \mathrm{mS} / \mathrm{cm}$ and $11.72 \mathrm{mg} / \mathrm{kg}$, respectively. The elements - K, Ca, Ti, Mn, Fe, Co, $\mathrm{Zn}, \mathrm{As}, \mathrm{Pb}, \mathrm{Rb}$ and $\mathrm{Sr}$ could be measured. The concentrations of $\mathrm{Cr}, \mathrm{Ni}$ and $\mathrm{Cu}$ were found below their detection limits $(<2.3,<0.36$ and $<0.28 \mathrm{in} \mathrm{mg} / \mathrm{kg}$, respectively). The mean concentrations of the elements - K, Ca, Ti, Mn, Fe, Co, Zn, As, Pb, Rb and Sr were found to be $94.8,68.5,16.6,2.68,129,1.19,0.23,0.70,0.32,0.62$ and $1.03 \mathrm{mg} / \mathrm{kg}$, respectively. The elemental concentrations in the samples appeared to be low. The sand used for the development of the RHTC was collected from the nearby river bed through dredging process. The present sand sample could be regarded as the sample which was cut out of the deep layer of the river bed containing no sediment. From the concentrations of the investigated elements, it was clear that the sample had not yet been contaminated. Compared to the elemental levels in sea beach sand, the present river bed sand samples showed the presence of the same elements at very much low level (Bari et al. 2002). The elemental levels in a sand sample depends on where it grows, what types of rocks and minerals present in it and the concentrations of associated elements in rocks and minerals. The average concentrations of the measured elements (K: 94.8, Ca: 68.5, Ti: 16.6, Mn: 2.68, Fe: 129, Co:1.19, Zn: 0.23, As: 0.70, Pb:0.32 mg/kg) were also very much lower than their mean natural values in soils $(\mathrm{K}: 1.36 \%$, Ca: $1.37 \%$, Ti: $0.46 \%$, Mn: 850 
$\mathrm{mg} / \mathrm{kg}$, Fe: $3.8 \%$, Co: $8 \mathrm{mg} / \mathrm{kg}$, Zn: $50 \mathrm{mg} / \mathrm{kg}$, As: $5 \mathrm{mg} / \mathrm{kg}$ and Pb: $10 \mathrm{mg} / \mathrm{kg}$ ) (Frank 1993).

Table 1. Elemental concentrations of different environmental samples of relocated hazaribagh tannery complex area.

\begin{tabular}{lllll}
\hline \multirow{2}{*}{ Elements } & \multicolumn{4}{c}{ Elemental concentrations (ppm) } \\
\cline { 2 - 5 } & Tannery complex sand & River water & River sediment & River fishes \\
\hline $\mathrm{K}$ & $77-114$ & $10.5-17.03$ & $122-241$ & $0.39-1.01 \%$ \\
$\mathrm{Ca}$ & $54.8-80.2$ & $138-211$ & $142-170$ & $0.68-2.29 \%$ \\
$\mathrm{Ti}$ & $13.3-21.8$ & - & $37.7-79.8$ & - \\
$\mathrm{Cr}$ & $<2.3$ & $<0.5$ & $5.85-6.52$ & $<0.1$ \\
$\mathrm{Mn}$ & $1.62-4.06$ & $0.28-0.56$ & $7.90-21.4$ & $<20.0$ \\
$\mathrm{Fe}$ & $111-153$ & $1.09-2.74$ & $523-977$ & $60.6-125$ \\
$\mathrm{Co}$ & $1.13-1.24$ & - & - & - \\
$\mathrm{Ni}$ & $<0.36$ & $<0.059$ & $0.98-1.21$ & $<6.2$ \\
$\mathrm{Cu}$ & $<0.28$ & $<0.039$ & $0.86-1.31$ & $<4.8-101$ \\
$\mathrm{Zn}$ & $0.16-0.28$ & $0.060-0.085$ & $1.04-2.65$ & $46.3-174$ \\
$\mathrm{As}$ & $0.06-0.10$ & $0.022-0.038$ & $0.21-0.41$ & $<2.7$ \\
$\mathrm{~Pb}$ & $0.25-0.44$ & $<12$ & $<0.20-0.39$ & $<0.3$ \\
$\mathrm{Rb}$ & $0.46-0.70$ & $0.007-0.010$ & $2.01-2.62$ & $2.84-61.8$ \\
$\mathrm{Sr}$ & $0.64-1.15$ & $0.36-0.57$ & $2.41-3.69$ & $12.3-38.0$ \\
\hline
\end{tabular}

The average values for $\mathrm{pH}, \mathrm{EC}, \mathrm{DO}, \mathrm{BOD}, \mathrm{SS}$ and DS in the samples were 8.02, $0.35 \mathrm{mS} / \mathrm{cm}, 6.29,4.21,0.06,0.36 \mathrm{mg} / \mathrm{l}$, respectively. The guideline values for $\mathrm{pH}, \mathrm{DO}$, BOD, DS in drinking water are 6.5-8.5, 6, 0.2, $1000 \mathrm{mg} / \mathrm{l}$, respectively (Water Quality Criteria 1997). The DS values of the samples were very much lower than the guideline value of drinking water. But the BOD value of the sample was higher than that of drinking water. The BOD for clean and fairly clean river water is $3 \mathrm{mg} / \mathrm{l}$, which is comparable with the present value (Taras 1975b). The river water did not need dilution as the BOD values of the samples did not exceed $5 \mathrm{mg} / \mathrm{l}$ (Taras 1975). The average concentrations of elements - K, Ca, Mn, Fe, $\mathrm{Zn}$, As, $\mathrm{Rb}$ and $\mathrm{Sr}$ measured in the river water samples were found to be $13.09,178,0.41,1.82,0.073,0.031,0.010$, and 0.48 in $\mathrm{mg} / \mathrm{l}$, respectively. The concentrations of $\mathrm{Cr}, \mathrm{Ni}, \mathrm{Cu}, \mathrm{Pb}$ were found below their minimum detection limits. In all water samples the average concentrations of the elements - K, Ca, Mn, Fe (K: 13.09, Ca: 178, Mn: 0.41, Fe:1.82 mg/l) were higher and the concentrations of the elements $\mathrm{Zn}$ and $\mathrm{As}(\mathrm{Zn}: 0.073$, As: $0.031 \mathrm{in} \mathrm{mg} / \mathrm{l})$ were lower than their respective drinking water guideline values $(\mathrm{K}: 12, \mathrm{Ca}: 75, \mathrm{Mn}: 0.1, \mathrm{Fe}: 0.3$ 1.0, Zn: 5, As: 0.05 in mg/l) (Water Quality Criteria 1997). Some anions - $\mathrm{SO}_{4}{ }^{-2}, \mathrm{PO}_{4}{ }^{-3}$, $\mathrm{Cl}^{-1}$ and $\mathrm{NO}_{3}^{-1}$ were also determined in the river water samples and their concentrations ranged from $0.028-0.088,0.014-0.028,15.1-16.3,4.12-7.11 \mathrm{mg} / \mathrm{l}$ with the average concentrations of $0.057,0.019,15.6,5.68 \mathrm{in} \mathrm{mg} / \mathrm{l}$, respectively. The drinking water guideline values for $\mathrm{SO}_{4}^{-2}, \mathrm{PO}_{4}^{-3}, \mathrm{Cl}^{-1}$ and $\mathrm{NO}_{3}^{-1}$ are 400, 6, $150-600$ and $10 \mathrm{mg} / \mathrm{l}$, respectively. Compared to the guideline values of drinking water, the concentrations of measured anions appeared to be very low. 
The elements - K, Ca, Ti, Cr, Mn, Fe, Ni, Cu, Zn, As, Rb, Sr and $\mathrm{Pb}$ could be measured in the river sediments and their mean concentrations were found to vary in the range of 122 - 241, 142 - 170, 37.7 - 79.8, 5.85 - 6.52, 7.90 - 21.4, 523 - 977, 0.98 - 1.21, $0.86-1.31,1.04-2.65,0.21-0.41,2.01-2.62,2.41-3.69$ and $0.27-0.38$ in $\mathrm{mg} / \mathrm{kg}$ with the average concentrations of $205,155,67,6.02,17.2,798,1.10,1.24,1.99,0.31,2.34$, 2.63 and $0.35 \mathrm{mg} / \mathrm{kg}$, respectively. The lowest effect levels in sediment (LELS) for Cr, $\mathrm{Mn}, \mathrm{Fe}, \mathrm{Ni}, \mathrm{Cu}, \mathrm{Pb}$ recommended by the Ontario Ministry of Environment and Energy, Canada are 26, 460, 20000, 16, 16, $31 \mathrm{mg} / \mathrm{kg}$, respectively (Ikem and Nyavor 2003). Compared to LELS the guideline values the present river sediment levels of those elements are very low. The global average values of fluvial sediment (GAFS) for $\mathrm{Cr}, \mathrm{Ni}$, $\mathrm{Cu}, \mathrm{Pb}$ are $90,32,33,19 \mathrm{in} \mathrm{mg} / \mathrm{kg}$, respectively (Jordao et al. 2002). The concentrations of the same elements in the present river sediment are much lower than those in GAFS. However, the sediment levels of elements are comparable with those of the tannery complex sand. The low concentrations of elements in the sediments might be due to the reason that the original surface sediment of the river might be replaced by the deep layer sand while dredging. A comparison of LELS, GAFS and the present sediment levels of elements (PSLH) is shown in Fig. 1.

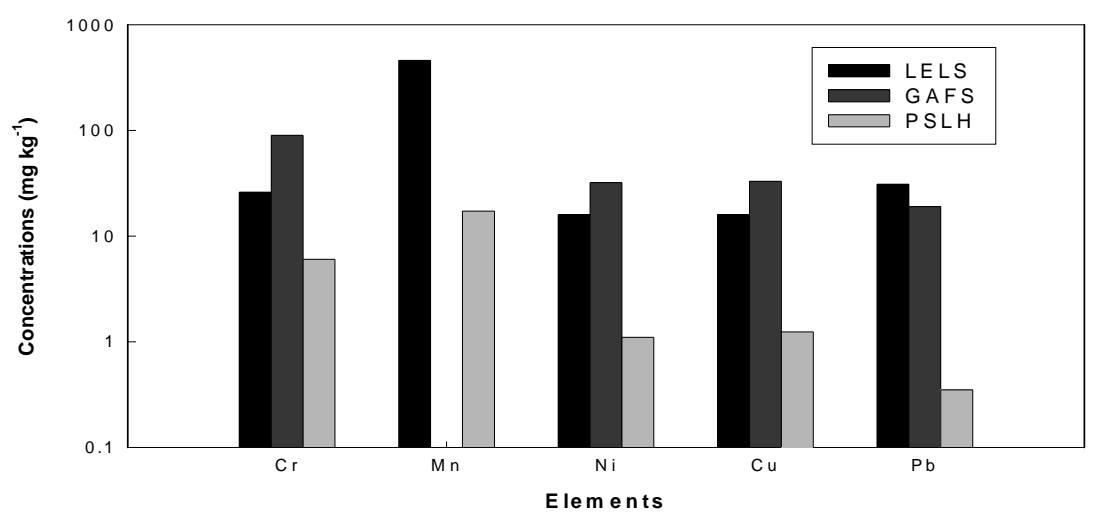

Fig. 1. Comparison of PSLH with LELS and GAFS.

LELS: Lowest effect levels in provincial sediment quality guidelines by the Ontario Ministry of Environment and Energy (Canada).GAFS: Global average of fluvial sediments. PSLH: Present sediment levels of heavy metals

Some fish locally known as tengra, puti, baim, taki, shrimp, chanda and baila were investigated for trace elements on dry weight basis. All varieties of samples showed the levels of $\mathrm{Cr}, \mathrm{Mn}, \mathrm{Ni}, \mathrm{As}, \mathrm{Cd}$ and $\mathrm{Pb}$ below their detection limits of $<0.1,<20,<6.2$, $<2.7,<0.3$ and $<0.3 \mathrm{mg} / \mathrm{kg}$, respectively. Some other elements $-\mathrm{K}, \mathrm{Ca}, \mathrm{Fe}, \mathrm{Zn}, \mathrm{Rb}, \mathrm{Sr}$ could be measured in all varieties of fishes and their concentrations were found to vary 
from $0.39-1.01 \%, 0.68$ - 2.29\%, 60.6 - 125, 46.3 - 174, $2.84-61.8$ and 12.3 - 38.0 $\mathrm{mg} / \mathrm{kg}$, respectively. Copper was measured only in puti and shrimp in which its concentrations were 7.24 and $101 \mathrm{mg} / \mathrm{kg}$, respectively. Earlier study showed that $\mathrm{Fe}, \mathrm{Cu}$ and $\mathrm{Zn}$ levels in sweet water fishes ranged from 31.80 - 296.02, 1.48 - 23.30, 33.01 $286.45 \mathrm{in} \mathrm{mg/kg} \mathrm{(d.w.b),} \mathrm{respectively} \mathrm{(Sharif} \mathrm{et} \mathrm{al.} \mathrm{1993).} \mathrm{According} \mathrm{to} \mathrm{another} \mathrm{study,} \mathrm{in}$ marine fish, levels of $\mathrm{Fe}, \mathrm{Cu}$ and $\mathrm{Zn}$ were found to vary from 60.55 - 450, 1.48 - 23.3 and $0.65-58.1 \mathrm{in} \mathrm{mg} / \mathrm{kg}$ respectively (Khan et al. 1987). It is seen that the reported results of $\mathrm{Fe}$ and $\mathrm{Zn}$ in both sweet water and marine fishes are in agreement with the results for these elements. The present findings show that $\mathrm{Cu}$ level in puti $(7.24 \mathrm{mg} / \mathrm{kg})$ is much lower than that of shrimp (101 mg/kg). The difference in metal contents of fishes in this case might be due to different bioaccumulation capabilities of different species as well as the aquatic environment, food habit and the geochemical variability.

\section{CONCLUSION}

The Relocated Hazaribagh Tannery Complex sand was found to have not yet been contaminated as indicated by its low elemental levels in comparison to those of the natural soil. The elemental concentrations and physicochemical characteristic values of river water were found to be comparable in some cases with the guideline values of drinking water. The concentrations of the elements in the river sediments were found to be in agreement with those of RHTC sand. All varieties of fishes - tengra, puti, baim, taki, shrimp, chanda and baila were found to contain the toxic elements $(\mathrm{Cr}, \mathrm{As}, \mathrm{Cd}$ and $\mathrm{Pb}$ ) below detection limits.

\section{REFERENCES}

Bari, Zahidul, K. R. Chowdhury, M. J. Jalalur Rahman and M. Ashraful Islam. 2002. Geochemical composition of the Neogene Sandstones and Recent Beach Sands Across the Inani-Dakhin Nhila Hillrange, Southeast Bangladesh. J. Bang. Geo. Sci. 8: 73-87.

Frank, V. 1993. The Chemistry of Soil. In: J. Toggyessay (Ed:), Chemistry and Biology of Water, Air, Soil Environmental aspects. Elsvier Science Publishers, Amsterdam, The Netherlands, pp. 694.

Ikem, A., N. O. Egiebor and K. Nyavor. 2003. Trace elements in water, fish and sediment from tuskegee lake, Southeastern, USA. J. Wat. Air and Soil Pollut. 149: 51-75.

Jordao, C.P., M. G. Perewira and J. L. Perreira. 2002. Metal contamination of river waters and sediments from effluents of Kaotin Processing in Brazil. J. Wat. Air. and Soil. Pollut. 140: $119-138$

Khan, A. H., M. Ali, S. K. Biswas and D. A. Hadi. 1987. Trace elements in marine fish from Bay of Bengal. J. Sci. Total Environ. 61: 121-130.

Sharif, A. K. M., M. Alamgir, A. I. Mutafa, M. A. Hossain and M. N. Amin. 1993. Trace element composition in ten species of freshwater fishes of Bangladesh. J. Sci.Total Environ. 138: 117126. 
Taras, Michael J. 1975. Water Analysis. In: Frank J. Welcher, Ph.D. (Ed), $6^{\text {th }}$ ed. Vol.11, Standard Methods of Chemical Analysis. Robert E. Krieger Publishing Co., Inc., Huntington, New York 11743, USA, pp. 2458-2461.

Water Quality Criteria. 1997. A Compilation of Environmental Laws Administered by the Department of Environment, The Ministry of Environment and Forest., The People's Republic of Bangladesh, Bangladesh Gazette Additional 28: 52-54.

(Received revised manuscript on 7 February, 2012) 